\title{
The drivers and barriers of corporate social responsibility: A comparison of the MENA region and Western countries
}

\author{
Amin Alizadeh*
}

\author{
1 Texas A\&M University; ameen59@tamu.edu.com \\ * Correspondence: ameen59@tamu.edu.com
}

Citation: Alizadeh., A..; The drivers and barriers of corporate social responsibility: A comparison of the MENA region and Western countries. Sustainability 2021, 13, x. https://doi.org/10.3390/xxxxx Received: $12 / 10 / 2021$ Accepted: 17/11/2021 Published:

Copyright: (C) 2021 by the authors. Submitted for possible open access publication under the terms and conditions of the Creative Commons Attribution (CC BY) license (https://creativecommons.org/license s/by/4.0/).

\begin{abstract}
Although numerous articles have been published to address drivers or barriers of corporate social responsibility (CSR), some parts of the world have received less attention. In this study, I reviewed the literature, from 2010 to 2021, to identify drivers and barriers of CSR in the the Middle East and North Africa (MENA) region and compare them with the findings in western countries. (2) Methods: For this study, I used a structured literature review method. By setting the inclusion and exclusion criteria, only 28 articles remained from selected database; (3) Results: The findings revealed some CSR drivers, such as leadership styles, profitability, reputation, moral commitment, and environmental conservation are common in both regions. There are also some differences between CSR drivers, for example religious beliefs, low concentration of ownership, and company characteristics are some of the drivers in the MENA region. Maintaining social license to operate, avoiding the risks of community opposition, pressure from the government, and consumer demand tend to be more important in western countries. Common barriers in both regions are lack of financial resources, cost, lack of CSR knowledge and awareness, and ownership concentration. This review also highlighted that lack of law enforcement, lack of stakeholder communication, lack of management commitment, lack of interests, corruption, and financial debts are some of the addressed barriers of CSR in the MENA region, while cost/benefit ratio, lack of customer interest, and lack of scientific frameworks are the special barriers in western countries. (4) Conclusions: While researchers in western countries have more focus on energy sector, there is a lack of research about drivers and barriers of CSR in the MENA region in several industries, including oil and gas.
\end{abstract}

Keywords: CSR drivers and barriers; corporate social responsibility, MENA, middle east, north Africa, north America, Australia, Europe, western countries.

\section{Introduction}

Across the globe, CSR is a famous and widespread concept. From political leaders and corporations to marketing and human resource practitioners, people have discussed this topic in detail. In this era, anyone who watches television or reads news will see multiple reports about for-profit companies' social activities, which mainly relate to protection and welfare of the environment and civil society. CSR is the act of adding ethical and moral responsibilities in an organization's goals and decision-making strategies [1]. In 1999, Carroll declared that large corporations have great decision-making power to influence the lives of everyone in society, and these decisions should be made by company leaders, based on societal values [2]. Nowadays, CSR activities have become a wide range of programs that highly impact an organization's core values. These activities are mainly focused on internal/external issues such as employees' work-life balance, employee needs, workplace safety, sustainability, human resource management, the environment, poverty, and community development [1].

Although numerous articles have published to address drivers or barriers of CSR in western countries, some parts of the world, such as developing countries, received less attention $[3,4]$.I also found there is a lack of updated review on CSR drivers and barriers 
considering geographical locations. Drivers point out to elements that predict the CSR practices and policies, and barriers address obstacles of implementing CSR practices and policies. In this study, I reviewed 28 journal articles from developing and developed countries from 2010 to 2021 and found out how drivers and barriers of CSR from different cultures and industries could be similar/different. In this study, the main question is what are the drivers and barriers of CSR? And, as a follow up question, I am trying to define if CSR drivers and barriers are distinct in different geographical regions. Despite extensive research on CSR, there is still limited knowledge on comparing CSR in western countries (In this article, western countries only consist of Australia, North America, and European countries) with rest of the world. This review will offer fresh and updated insights into the growing CSR literature.

\section{Definition of Corporate Social Responsibility}

Practitioners have used many different terms to address CSR practices, such as social responsibility of business, corporate responsibility, corporate citizenship, business responsibility, corporate social performance, corporate sustainability, corporate supply chain social responsibility, and corporate conscience. Reviewing the literature revealed that there is no single, generally accepted definition for CSR [2]. However, in Social Responsibilities of the Businessman, the author proposed one of the earliest definitions for social responsibility of business [5]. According to Carroll, who also proposed one of the most influential definitions for CSR [6], in 1960, Keith Davis provided a leading and crucial definition for CSR [7]. The commission of the European communities - also known as the European Commission - release CSR definitions every year since 2001 and their definitions have been referred several times by academic scholars $[9,10,11]$. In table 1 , I provided 10 ‘well known' definitions of CSR.

Table 1. definitions of CSR

\begin{tabular}{cl}
\hline Author (year) & Definition \\
\hline Bowen (1953) & "The obligations of businessmen to pursue those policies, to make \\
those decisions, or to follow those line of actions which are desira- \\
ble in terms of the objectives and values of our society" (p. 6).
\end{tabular}
cordance with shareholders' desires, which generally will be to make as much money as possible while conforming to the basic rules of society, both those embodied in law and those embodied in ethical custom" (p.32).

Carroll (1979)

"The social responsibility of business encompasses the economic, legal, ethical and discretionary expectations that society has of organizations at a given point of time" (p.500).

Maignan and Ferrell, (2000) “The extent to which businesses meet the economic, legal, ethical, and discretionary responsibilities imposed on them by their stakeholders" (p. 284).

McWilliams and Siegel (2001) "Situations where the firm goes beyond compliance and engages in actions that appear to further some social good, beyond the interests of the firm and that which is required by law" (p.117). 


\begin{tabular}{cl}
\hline Rupp et al. (2006) & $\begin{array}{l}\text { "Activities, decisions, or policies, that organizations engage in to } \\
\text { effect positive social change and environmental sustainability" (p. } \\
537) .\end{array}$ \\
European Commission (2011) & "The responsibility of enterprises for their impact on society." [8] \\
Aguinis and Glavas (2012) & "Context-specific organizational actions and policies that take into \\
& $\begin{array}{l}\text { account stakeholders' expectations and the triple bottom line of } \\
\text { economic, social, and environmental performance" (p.933). }\end{array}$ \\
Rasche et al. (2017) & $\begin{array}{l}\text { "The integration of an enterprise's social, environmental, ethical } \\
\text { and philanthropic responsibilities towards society into its opera- } \\
\text { tions, processes and core business strategy in cooperation with rel- } \\
\text { evant stakeholders" (p.6). }\end{array}$
\end{tabular}

Scholars do not have an agreement on dimensions of CSR, but the majority of CSR pioneers include, stakeholders, social, and environmental dimensions as the foundation $[12,13,14]$. McWilliams and Siegel affirmed that CSR has two dimensions of social and voluntariness, as social responsibility goes beyond economic and legaldimensions [15]. Other researchers proposed CSR focus needs to be on community, environment, employees, and customers $[16,17]$. They excluded the government and economic dimensions of CSR and affirmed legal requirements are not part of CSR activities [16]. In this study, I follow Rasche et al. definition as social, environmental, ethical and philanthropic dimensions are the main basis for CSR [18].

\section{Methods}

For this study, I used structured literature review method [19]. Due to pursuing these methods, Iidentified data points in literature that inform new or emerging concepts by conducting structured steps of analysis. I contend that in order to develop a better understanding of the CSR drivers a focus on different geographic region is needed, as several studies have shown CSR drivers might varies based on different culture and countries $[20,21]$. Although there have been several review articles published related to CSR drivers, there is a lack of review that highlight the differences between various cultures and countries.

Journal articles were sourced from ABI/Inform complete, Business Source Complete, ERIC (EBSCO), and Web of Science. The keyword search was to identify articles containing corporate socialOR social responsibility OR corporate philanthropy OR corporate citizenship OR CSR in the title of study and drivers OR barriers OR antecedents anywhere in the paper. As CSR is an emerging and evolving topic, I decided to have current and scholarly resources in this evolving field by limiting the search to only empirical articles that have been published after 2010 in English language. The initial search generated 2,282 articles in the selected database (table 1 ).

Table 2. Inclusion criteria.

\begin{tabular}{cc}
\hline Inclusion Criteria & Rationale \\
\hline $\begin{array}{c}\text { Title must have corporate social or social responsibil- } \\
\text { ity or CSR or corporate philanthropy or corporateciti- } \\
\text { zenship as the focus of the study. }\end{array}$ & $\begin{array}{c}\text { To reduce the chance of collecting unre- } \\
\text { la ted articles }\end{array}$ \\
$\begin{array}{c}\text { Abstract must show clearindication of drivers or bar- } \\
\text { riers of corporate social responsibility. }\end{array}$ & $\begin{array}{c}\text { The focus of the research is to study driv- } \\
\text { ers and barriers of corporate social respon- } \\
\text { sibility }\end{array}$ \\
\hline
\end{tabular}

Title must have corporate social or social respon sibilzenship as the focus of the study. lated articles sibility 

Country/geographical region need to be clear in the rizing them into two groups based on culabstract a nd has to be among MENA or western coun- tural simila rities and geographical locatries. tions.

Article must be written in English

English is the dominating research language in the field of corporate social responsibility.

Article must be Qualitative, Quantitative, or mixed I only wanted to analyze empirical studies. method

Only empirical articles from 2010

To focus on the current drivers and barriers.

For identifying articles from western countries, I added an extra row with name of 26 European countries included in Schengen area with US, UK, Canada, and Australia. For US, I added U.S.A. or USA, or United States, or U.S. or US, or America. And for UK, I added United Kingdom, England, and Scotland. While different organizations defined MENA differently, for this study, I included 19 countries from Middle East and North Africa by following "WorldAtlas" organization [22]. In order to identify MENA related studies, I added an extra row of countries' names as follow: Algeria OR Bahrain OR Egypt OR Iran OR Iraq OR Israel OR Jordan OR Kuwait OR Lebanon OR Libya OR Morocco OR Oman OR Palestine OR Qatar OR Saudi Arabia OR Syria OR Tunisia OR United Arab Emirates OR UAE OR Yemen. The country name had to appear in the abstract. with this additionallimit, the total number of founded articles reduced as follow. After removing duplicates and reading the abstracts for find appropriate papers only 9 articles for MENA region remained.

Table 3. Number of collected articles for MENA region.

\begin{tabular}{cccc}
\hline Database & $\begin{array}{c}\text { Number of } \\
\text { Collected Articles }\end{array}$ & $\begin{array}{c}\text { Number of Collected } \\
\text { Articles for Western } \\
\text { countries }\end{array}$ & $\begin{array}{c}\text { Number of Collected } \\
\text { Articles for MENA } \\
\text { region }\end{array}$ \\
\hline $\begin{array}{c}\text { ABI/inform } \\
\text { Business Source }\end{array}$ & 495 & 131 & 8 \\
Complete & 1114 & 148 & 8 \\
ERIC(EBSCO) & 10 & 2 & 2 \\
Web of Science & 663 & 125 & 9 \\
TotalFirst Step & 2282 & 406 & 27 \\
Collected for Analysis & & 19 & 9 \\
\hline
\end{tabular}

An inclusive a pproach would demand to include all of the 406 articles from Western countries for the review, but this way was deemed inefficient while I only had 9 articles from the MENA region to compare. Alternatively, I decided to adopt a statisticalmethod to form a representative random sample from the 406 articles. To be ninety percent certain of being accurate to within +0.1 , and -0.1 of the true proportion of all articles, a minimum sample size of 41 articles was needed from this region [21]. I increased the sample to 60 articles to lower the probability of Type II error. In the second step, I followed the inclusion criteria rules (table 2). Initially, I reviewed only abstracts and skimmed the methodology section to determine relevancy of the articles and in the final step, reviewing the chosen one in depth. I reviewed articles that contained drivers of CSR in depth. A total of 19 articles were selected to compare with 9 articles from the MENA region. By identifying irrelevant papers in the final step, only 28 papers remained in this selection process (figure 1). 


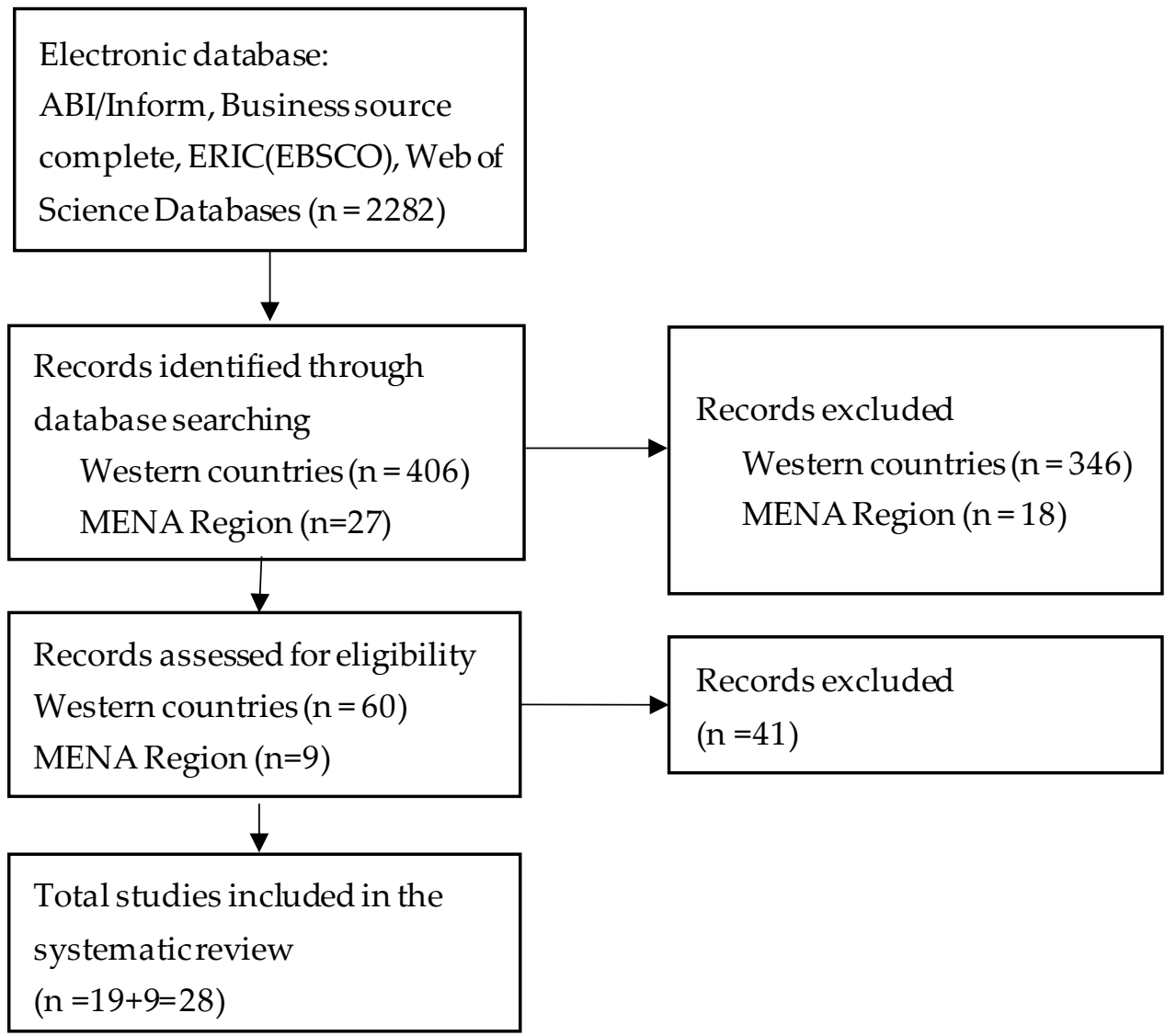

Table 4 presents the distributions of the selected journal articles. Reviewing the selected articles revealed that a majority of studies were published in one of the four journals: Journal of business ethics, Social Responsibility Journal, Sustainability, and Corporate Social Responsibility and Environmental Management. There are 13 qualitative and 15 quantitative studies in this selection and 15 studies collected their data from more than one industry.

Table 4. Journal titles and number of articles found

Name of Journals Number of articles

Journal of business ethics 10

SocialResponsibility Journal

Corporate Social Responsibility and Environmental Management

Sustainability

The Extractive Industries and Society

The Journal of Asian Finance, Economics, and Business

Corporate Reputation Review

International Business Review

Business Strategy Series

International Journal of Entrepreneurial Knowledge

Energy Policy

Spanish Journal of Finance and Accounting

Journal of Financial Reporting and Accounting

The countries or regions included in CSR studies were identified and are presented in Table 5 . The 28 papers covered eighteen countries or regions including both the MENA region and western (developed) countries. Of these, most of the papers focused on developed countries; the United States (five) and Australia (three) had the most contribution, respectively. Four articles focused on multi-country analysis (e.g., European firms, Nordic countries). 
Table 5. Distribution of selected papers by country or region

\begin{tabular}{cll}
\hline No. & Country or region & Number of selected papers \\
\hline 1 & United States & 5 \\
2 & Australia & 3 \\
3 & Norway & 2 \\
4 & Sweden & 2 \\
5 & Iran & 2 \\
6 & Saudi Arabia & 2 \\
7 & European firms & 1 \\
8 & Nordic countries & 1 \\
9 & Netherland & 1 \\
10 & Spain & 1 \\
11 & United Kingdom & 1 \\
12 & North America and Western Europe \\
13 & Egypt & 1 \\
14 & France & 1 \\
15 & Jordan & 1 \\
16 & Morocco & 1 \\
17 & U.A.E & U.A.E., Lebanon, \& Tunaisia \\
18 & 1 \\
\hline
\end{tabular}

\section{Corporate Social Responsibility Drivers}

In this section, the goal is to find out what are the drivers of CSR and declare if geographical location and different culture have any impact on CSR antecedents. By drivers, I aim to discover factors that work as predictors, motives or forces that lead to CSR implementation in organization, either willingly or unwillingly. Majority of companies engage in CSR practices due to institutional and stakeholders' pressures [22]. Aguinis and Glavas classified CSR drivers into individual, organizational and institutional levels and declared majority of articles studied CSR drivers at the organizational level. Several other scholars divided CSR drivers in three categories: value driven, performance driven, and stakeholder driven $[23,24]$. The two mentioned studies described the value driven is referred to a self-motivated approach and depends on external pressures. They also explained performance related drivers depends on the corporation's economic benefits, it also contains company reputation and image, while stakeholder driven forces depends on stakeholders demands toward CSR activities. In previous studies majority of scholars categorized the CSR drivers into external and internal [25,26,27], and recently some articles attempt to study CSR antecedents by dividing them into three groups of internal, connecting, and external drivers to engage in CSR [28,29].

Drivers of CSR may differ with respect to largeness of the company and degree of internationalization [30]. Dhanesh confirmed different cultures might have various drivers for CSR [31]. [32] reviewed the literature and declared generally leader demographic characteristics, and personal values are important drivers that might impact on CSR formation. One study compared Sweden and Taiwan by using World Value Surveys (WVS) data and revealed national culture, besides education, play a critical role in shaping CSR drivers [19]. I reviewed the literature from 2010 to 2021 to explore the main drivers of CSR. In table 5, I analyzed 28journal articles that studied CSR antecedents from different countries. As majority of journal articles have focused on North America, Europe, and Australia studies, my main emphasis was to discover MENA region perspectives to make the comparison easier. All of the drivers and barriers of CSR have been identified by analyzing organizations' documents or by surveying the companies' em ployees, business leaders, and managers. Therefore, these findings do not represent consumers 
perspective. In the following section I addressed my findings from Middle East, and North Africa (MENA), and North America, Europe, and Australia.

\section{Middle East, and North Africa (MENA)}

While the concept of CSR has been analyzed in depth in western countries, there is a dearth of empirical research in developing nations like the MENA region [32]. One of the latest studies examined the determinant factors of CSR in 94 Jordanian companies from manufacturing and service industries [33]. Their findings revealed that (a) Company maturity, profitability, and size have positive impacts on CSR participation; (b) High percentage of debt to assets is a barrier to Jordanian companies' participation in socially responsible activities; (c) Family-owned companies have less incentive to engage in CSR activities; and (d) Low concentrated ownership and media coverage are also accounted as drivers of CSR engagement.

In Morocco, researchers conducted a qualitative study by using semi-structured interviews, focus session, and observations in the phosphate mining industry [35]. They affirmed that the most determining driver of CSR was the uprising of mining communities after the Arab Spring. They declared one of the underlying reasons for CSR activities was to defend their reputation and secure the mine production. Another study was conducted in Saudi Arabia and identified the main drivers of CSR are improvement of corporate image and moral commitment [36].

Another study surveyed 105 executives from Iranian manufacturing organizations from various industries [37]. He found religious beliefs are one of the main drivers of CSR in Iran. Based on this study, enhanced corporate identity, corporate reputation, and attracting more customers are other im portant drivers of CSR. Other scholars interviewed thirteen experienced Iranian business professionals and affirmed the main CSR drivers are branding, profitability, community welfare, quality improvement, customer retention and environmental conservation [38]. While many interviewees believed that CSR could have positive impacts on companies' reputations, some professionals declared that CSR is a forgotten element of businesses in Iran.

A survey study hired 740 participants from U.A.E., Lebanon, and Tunaisia and introduced participative leadership as a driver of CSR [33]. Later on, [39] surveyed $752 \mathrm{em}$ ployees from trading and service industries and identified servant leadership as a strong antecedent of internal CSR.

\section{North America, Europe, and Australia}

Laudal in 2011 surveyed managers in the Norwegian clothing sector and identified five main drivers and three barriers of CSR in small and medium-sized enterprises (SME) and multinational enterprises (MNE) [30]. He declared companies tend to follow practices of leading companies in their field. He called this strategic behavior as "following leading companies." Some corporations engage in CSR activity as mutually beneficial partnerships that enhance local and public reputation, via showing social and environmental responsibility [30]. Laudal also displayed that CSR could work as a strategictool for corporations to diminish market risks, create market opportunities, and get involved in public policy decision-making processes. In other words, they may use CSR as a tool to influence or even change public regulations.

A Norwegian study surveyed business students, CEOs, and NGO employees in Norway to compare different perspectives and identify what motivates mangers to adopt CSR [40]. Their findings revealed that all of the three groups are in an agreement that the key 
drivers for business leaders are branding (to create a positive reputation and brand image), stakeholders (to satisfy different stakeholders), and value maximization (to create long-term value for shareholders). Boukattaya and Omri studied 96 French firms and analyzes the link between board characteristics and CSR. They revealed women are more sensitive to CSR engagement and ethical challenges, therefore, board gender diversity has positive impact on CSR implementation [41].

Chkanikova and Mont identified the drivers and barriers for Sweden food retailers [42]. Pressure from the government and European Union, strengthening reputation and brand name, and consumer demand for greener and healthier products are some of the drivers. They also found many retailers engaged in socially responsible activities such as improving eco-efficiency to reduce the operational costs. Another driver is industrial norms, agreements, and certifications that force retailors to follow the agreement for sustainability improvement. Another study in Sweden found that CSR is an outcome of employees' motivations in workplace [43]. The study also described that CSR implementation in SMEs in the apparel industry is driven by employees' perceptions of moral responsibility for CSR [43].

One study analyzed the gas mining industry in Australia and summarized the main reason for participation in CSR is to maintain their social license to operate and avoid the risks of community opposition [44]. Another study reviewed the literature to identify how CSR has been implemented in the Britain construction industry and revealed that good reputation among the publicand demand to increase credibility are two main antecedents of CSR in this industry [45]. Bolton, Kim, and O'Gorman studied a Britishenergy company and stated the organization was engaged in CSR to safeguardits reputation and position itself in ranking indices [46]. Another study examined RoyalDutch Shell which is one of the biggest corporations in the oil sector and found profitability is one of the key drivers of CSR programs [47].

Lozano defined the drivers of CSR participation could be due to internal or external motivations [29]. He conducted 16 semi-structured interviews with top-level corporate managers and experts in the field. All of the interviewees were working in North American or Western European organizations. His findings revealed reputation, customer demands and expectations, and regulation and legislation are the main external drivers of CSR, while business strategy, corporate culture, cost savings and profitability, environmental performance and climate change adaptation and mitigation, and risk prevention and risk management are the main internal drivers.

Godos-Díez et al surveyed 101 organizations in Spain and studied the impacts of companies' ownership structure and top management characteristics on CSR implication [48]. They claimed corporations are framed with the values of their CEOs, when the CEO's are free to act. Their study released that ownership concentration and certain manager characteristics will positively influence the implementation of CSR practices. In contrast, two scholars examined 700 European multinational firms from 15 countries and $35 \mathrm{in}$ dustries and found more concentrated ownership is a barrier to CSR [49].

Fabrizi, Mallin, and Michelon studied 597 US firms and found out personalincentives of CEOs had the significant effect on CSR decisions of companies, for instance CEOs who are new to the company (or role) and need to gain legitimacy from stakeholders are more likely to engage in CSR activities [50]. Their review also revealed there are four main CSR drivers in US companies which are moral obligation, sustainability, license to operate, and company reputation. In different study, a major Australian bank was analyzed by eleven in-depth interviews and participating in nine meetings and forums. 
Their findings revealed leadership styles and values could be institutional drivers of CSR [51].

Jo and Harjoto analyzed 3000 U.S. organizations from the Kinder, Lydenberg, and Domini's (KLD's) Stats database. They explored the effects of corporate governance on CSR engagement, they found CSR engagement is driven by corporate governance and monitoring systems, such as board leadership, board independence, institutional ownership, analyst following, have the most significant and positive effect on firm decision to engage in CSR [52]. They emphasized that CSR is a supplement of corporation's activities to adopt successful corporate governance, securing corporations' sustainability through ethical business practices.

Jin, and Drozdenko surveyed IT professionals in the United States and explored the relationships between organizational values, organizational ethics, and CSR [53]. Their finding revealed that managers from companies with organic core values (e.g., democratic, open, trusting) have greater level of social responsibility compare to the one with mechanistic values (e.g., structured, regulated, closed). They also found that managers who are more ethical tend to be more socially responsible [53]. Another study in The United States surveyed 466 managers from different industries and declared that organizational core values significantly affect CSR [54]. They also declared corporations which are more socially responsible earn higher profits in this country.

\section{Corporate Social Responsibility barriers}

There is a need to certain level of financial freedom before investments in CSR can be expected from SMEs [30]. It is also suggested that implementing CSR needs a capacity to devote time, knowledge and facility in an area where no immediate returns on investment could be expected. Laudal called the two mentioned barriers as insufficient cost/benefit ratio and external control which are two factors for SMEs that make CSR practices unreachable source of competitive edge. He also addressed "internal control" as one major barrier for large MNEs, and found when the number of suppliers and internal departments increase, the self-interest of each gent may be in conflict with the CSR objectives and create a barrier for CSR implementation [30].

Chkanikova and Mont addressed several barriers that retailers are facing to enroll in socially responsible actions [42]. They found lack of governmental leadership to support the transition, lack of financial resources, lack of knowledge and expertise, and high costs of sustainable products are some of the barriers. Globalization and competitive environment in retail industry caused that customers search for cheap food or product. This barrier created a challenging situation for supermarkets to implement sustainability improvements.

One study mentioned there are several barriers for organizations to implement CSR in Iran [37]. Culturally people tend to keep their charitable acts and good deeds confidential. businessowners prefer to participate in socially responsible activities confidentially for religious beliefs and not to show off or take advantage out of it for their lives. Due to economic condition in Iran, entrepreneurs are more focused on short-term goals than on developing longer-term strategies such as CSR. He also found that many business owners believe the government should be more accountable for social responsibility. Lack of knowledge is also another addressed barrier [37].

El-Bassiouny conducted a qualitative study in Egyptian companies and concluded that the main barriers on CSR implementation are ineffective regulatory and governance systems, high levels of corruption, lack of top management commitment, and insufficient 
levels of CSR expertise [55]. Alotaibi, Edum-Fotwe, and Price studied the barriers to CSR implementation within construction industry in Saudi Arabia [56]. They identified eleven CSR barriers by reviewing the literature and interviewing with local CSRexperts, then they surveyed 137 respondents from two companies HR and overarching management departments. Their finding revealed there are seven main barriers for CSR such as: additional costs; lack of awareness and knowledge; lack of guidelines and coherent strategy; lack of stakeholder communication; lack of law enforcement; lack of training; and unclear project requirements.

Fabrizi, Mallin, and Michelon claimed CEO's and shareholders' monetary interests have a negative effect on CSR implementation [50].[57] tried to identify the main barriers of CSR activities in North European energy companies. Their research is based on empirical data obtained from interviews involving high-level managers from the largest suppliers of energy in the Nordic region. They addressed seven barriers at the individual level, seven at the organizationallevel, and three at the institutional level of analysis (see table5).

Table 5. Drivers and barriers of CSR

\begin{tabular}{|c|c|c|c|}
\hline Author/year & Drivers / Level & Barriers & Location/industry/method \\
\hline $\begin{array}{l}\text { Angus-Leppan, Metcalf, \& } \\
\text { Benn, (2010) }\end{array}$ & $\begin{array}{l}\text { Leadershipstyles } \\
\text { And values }\end{array}$ & & $\begin{array}{l}\text { Australia/Banking/Qualita- } \\
\text { tive }\end{array}$ \\
\hline Jin, and Drozdenko, (2010) & $\begin{array}{l}\text { Having ethical managers } \\
\text { with organic core values } \\
\text { (e.g., democratic, open, trust- } \\
\text { ing) }\end{array}$ & & US/IT industry/Quantitative \\
\hline $\begin{array}{l}\text { Ditlev-Simonsen \& Midttun, } \\
\text { (2011) }\end{array}$ & $\begin{array}{l}\text { Branding, stakeholders, and } \\
\text { value maximization }\end{array}$ & & $\begin{array}{l}\text { Norway/Mix indus- } \\
\text { tries/Quantitative }\end{array}$ \\
\hline $\begin{array}{l}\text { Bolton, Kim, \& O' Gorman } \\
\text { (2011) }\end{array}$ & $\begin{array}{l}\text { safeguard their reputation, } \\
\text { position themselves in rank- } \\
\text { ing indexes }\end{array}$ & & $\begin{array}{l}\text { UK/energy company/Quali- } \\
\text { tative }\end{array}$ \\
\hline $\begin{array}{l}\text { Ekatah, Samy, Bampton, \& } \\
\text { Halabi, (2011) }\end{array}$ & Profitability & & $\begin{array}{l}\text { Netherland/Oil and } \\
\text { Gas/Qualitative }\end{array}$ \\
\hline$\overline{\text { Valmohammadi (2011) }}$ & $\begin{array}{l}\text { Increase of corporate iden- } \\
\text { tity, and } \\
\text { Increase general reputation, } \\
\text { Religious beliefs, } \\
\text { Attract customers, }\end{array}$ & $\begin{array}{l}\text { Lack of knowledge or } \\
\text { awareness of CSR, } \\
\text { Corporations believe the } \\
\text { government should be re- } \\
\text { sponsible for sustainable de- } \\
\text { velopment and not for-profit } \\
\text { sector, }\end{array}$ & $\begin{array}{l}\text { Iran/Mix industries/Quanti- } \\
\text { tative }\end{array}$ \\
\hline$\overline{\text { Jo and Harjoto (2011) }}$ & Corporate governance & & $\begin{array}{l}\text { US/Mix industries /Quantita- } \\
\text { tive }\end{array}$ \\
\hline$\overline{\text { Laudal (2011) }}$ & $\begin{array}{l}\text { The need for good corporate } \\
\text { reputation, } \\
\text { Following leading compa- } \\
\text { nies, } \\
\text { Sensitive to public and local } \\
\text { perceptions, } \\
\text { To ward off government reg- } \\
\text { ulation (autonomy), } \\
\text { Geographicalspread(risk), }\end{array}$ & $\begin{array}{l}\text { Cost/benefit ratio } \\
\text { (Capacity) } \\
\text { External control (risk) } \\
\text { Internal control (risk) }\end{array}$ & $\begin{array}{l}\text { Norway/clothing indus- } \\
\text { try/Quantitative }\end{array}$ \\
\hline
\end{tabular}




\begin{tabular}{lll}
\hline Dam, and Scholtens(2013) & \multicolumn{1}{c}{$\begin{array}{l}\text { Ownership } \\
\text { concentration }\end{array}$} & $\begin{array}{l}\text { European firms/mixed in- } \\
\text { dustries /Quantitative/ }\end{array}$ \\
\hline Ghasemi and Nejati (2013) & $\begin{array}{l}\text { branding, profitability, com- } \\
\text { munity welfare, quality im- } \\
\text { provement, customer reten- } \\
\text { tion and environmental con- } \\
\text { servation }\end{array}$ & Iran/Mixed/Qualitative \\
\hline $\begin{array}{l}\text { Jin, Drozdenko, \& De- } \\
\text { Loughy, (2013) }\end{array}$ & Organizational core values & \\
\hline Arli, \& Cadeaux, (2014) & $\begin{array}{l}\text { stakeholder's salience } \\
\text { (power, legitimacy, urgency) }\end{array}$ & $\begin{array}{l}\text { US/mixed industries/Quan- } \\
\text { titative }\end{array}$ \\
\hline
\end{tabular}

Fabrizi, Mallin, and Michelonpersonal incentives of CEOs CEO and shareholders' mon-US/mix industries/Quantita(2014) etary interests tive

\begin{tabular}{|c|c|c|c|}
\hline$\overline{\text { Bashtovaya(2014) }}$ & $\begin{array}{l}\text { The moral responsibility of } \\
\text { doing the right thing }\end{array}$ & & US/Oil industry/Qualitative \\
\hline $\begin{array}{l}\text { Godos-Díez, Fernández- } \\
\text { Gago, Cabeza-García, \& Mar } \\
\text { tínez-Campillo (2014) }\end{array}$ & $\begin{array}{l}\text { Top management character- } \\
\text { r-istics, } \\
\text { ownership } \\
\text { concentration }\end{array}$ & & $\begin{array}{l}\text { Spain/mix industries/Quan- } \\
\text { titative/ }\end{array}$ \\
\hline$\overline{\text { Lozano (2015) }}$ & $\begin{array}{l}\text { External drivers: reputation, } \\
\text { customer demands and ex- } \\
\text { pectations, and } \\
\text { regulation and legislation. } \\
\text { Internal drivers: business } \\
\text { strategy, corporate culture, } \\
\text { cost savings and profitability, } \\
\text { environmental performance } \\
\text { and climate change adapta- } \\
\text { tion and mitigation, and risk } \\
\text { prevention and risk manage- } \\
\text { ment. }\end{array}$ & & $\begin{array}{l}\text { North America } \\
\text { and Western Europe/Mixed } \\
\text { industries/Qualitative }\end{array}$ \\
\hline Chkanikova, \& Mont (2015) & $\begin{array}{l}\text { Pressure from government } \\
\text { and European Union, } \\
\text { Stakeholder demands, } \\
\text { Strengthening reputation } \\
\text { and brand, } \\
\text { Consumer demand, } \\
\text { Industrial norms, } \\
\text { Lack of unhealthy food, } \\
\text { GMOs, and pesticide use, } \\
\text { NGO campaigns, } \\
\text { Media attention, } \\
\text { Scientific alerts, }\end{array}$ & $\begin{array}{l}\text { Lack of governmental leader- } \\
\text { ship to support retailers, } \\
\text { lack of financial resources, } \\
\text { Lack of knowledge and ex- } \\
\text { pertise, } \\
\text { More costs for sustainable } \\
\text { products, } \\
\text { Lack of customer interest, } \\
\text { Lack of scientific framework, }\end{array}$ & $\begin{array}{l}\text {-Sweden/Food retail industry/ } \\
\text { Qualitative }\end{array}$ \\
\hline Curran (2017) & $\begin{array}{l}\text { To maintain their social li- } \\
\text { cense to operate and avoid } \\
\text { the risks of community op- } \\
\text { position }\end{array}$ & & $\begin{array}{l}\text { Australia/Gas mining sector/ } \\
\text { Qualitative }\end{array}$ \\
\hline $\begin{array}{l}\text { Lythreatis, Mostafa, and } \\
\text { Wang, (2019) }\end{array}$ & Participative leadership & & $\begin{array}{l}\text { U.A.E., Lebanon, \& Tun- } \\
\text { aisia/mixed industries/ } \\
\text { Quantitative }\end{array}$ \\
\hline
\end{tabular}




\begin{tabular}{|c|c|c|c|}
\hline Sendlhofer, (2020) & $\begin{array}{l}\text { Employee moral responsibil- } \\
\text { ity }\end{array}$ & & $\begin{array}{l}\text { Sweden/Apparel Industry/ } \\
\text { Qualitative }\end{array}$ \\
\hline $\begin{array}{l}\text { Alotaibi, Edum-Fotwe, } \\
\text { \&Price (2019) }\end{array}$ & & $\begin{array}{l}\text { Additional costs; lack of } \\
\text { awareness and knowledge; } \\
\text { lack of guidelines and coher- } \\
\text { ent strategy; lack of stake- } \\
\text { holder communication; lack } \\
\text { of law enforcement; lack of } \\
\text { training; and unclear project } \\
\text { requirements }\end{array}$ & $\begin{array}{l}\text { Saudi Arabia/construction in- } \\
\text { dustry/Quantitative }\end{array}$ \\
\hline$\overline{\text { Pinto \& Allui (2020) }}$ & $\begin{array}{l}\text { improvement of corporate } \\
\text { image and moral commit- } \\
\text { ment }\end{array}$ & $\begin{array}{l}\text { Lack of management com- } \\
\text { mitment, lack of investors' } \\
\text { interests, lack of economicre- } \\
\text { sources, lack of employees' } \\
\text { competencies }\end{array}$ & $\begin{array}{l}\text { Saudi Arabia/manufacturing } \\
\text { and service/Quantitative }\end{array}$ \\
\hline Mehahad \& Bounar (2020) & $\begin{array}{l}\text { Uprising of mining commu- } \\
\text { nities after the Arab Spring }\end{array}$ & & $\begin{array}{l}\text { Morocco/Mining industry/ } \\
\text { Qualitative }\end{array}$ \\
\hline El-Bassiouny, (2020) & & $\begin{array}{l}\text { ineffective regulatory and } \\
\text { governance systems, rela- } \\
\text { tively high levels of corrup- } \\
\text { tion, lack of top management } \\
\text { commitment, and insufficient } \\
\text { levels of CSR expertise }\end{array}$ & $\begin{array}{l}\text { Egypt/Egyptian companies/ } \\
\text { Qualitative }\end{array}$ \\
\hline
\end{tabular}

Lythreatis et al (2021) Servant leadership
aisia/trading and service industries/Quantitative

\begin{tabular}{ll}
\hline Ananzeh, Alshurafat, \& & $\begin{array}{l}\text { Company characteristics } \\
\text { Hussainey (2021) }\end{array}$ \\
& $\begin{array}{l}\text { Age, size, profitability, me- ownership debts and family } \\
\text { dia exposure, and low con- } \\
\text { centration of ownership) }\end{array}$ \\
\hline Boukattaya \& Omri (2021) & Board gender diversity
\end{tabular}

Boukattaya \& Omri (2021) Board gender diversity France/mixed industries/ Quantitative

Latapí, Jóhannsdóttir, Davíððsdóttir, \& Morsing (2021) individual level: company's Nordic countries/Qualitanegative contribution to soci-tive/ energy sector ety; decision-making based on egocentrism; lack of CSR fit, motivation, and commitment; lack of CSR knowledge and awareness; lack of CSR leadership; lack of organizational support; and negative attitude toward CSR Organizational level: lack of flexibility and adaptability; lack of integration of CSR to the core business; lack of organizational trust; lack of understanding of the context; limited access to resources; misalignment of the corporate culture; and unfit 
organizational structure in-

stitutionallevel: cognitive;

normative, and regulatory

barriers

\section{Discussion}

This review of the literature indicates that empirical research on CSR drivers and barriers is very limited in the MENA region. For this region, only nine papers have been found during the literature review process and four out of nine studies collected their data without having focus on any specific industry, while the rest have analyzed manufacturing, trading, service, mining, and construction industries. In contrast, researchers in western countries have more focus on the energy sector by having five studies have concentrated on the energy industry. Majority of studies in western countries were Qualitative (eleven out of nineteen) while only three out of nine studies in the MENA region were Qualitative. This study was not able to identify CSR drivers or barriers in some industries, such as healthcare and hospitality, due to lack of research in these sectors.

In order to fill the gap, researchers need to focus on energy related companies, including oil and gas corporations in the MENA region. This region is a particularly interesting area to study social responsibility drivers and barriers because of its historical and cultural heritage. The region was the place of Persia and Kemet which were two of the oldest civilizations in the world with histories of valuing societal concerns. Other countries also have very rich cultural backgrounds; at the same time, MENA has the world's largest oil reserves and is responsible for the vast amounts of toxic air and water pollution and is one of the largest sources of greenhouse gas emissions in the world. There is a need to have more focus on this sector to identify the main drivers and barriers of CSR and plan for more engagement in effective activities and reduce their im pact on the climate crisis.

\section{Limitations}

There are several limitations that have to be considered. This review was limited to only empirical articles that have been published after 2010 in the English language. The selection of the publications was also limited to four scientific databases and followed a specific selection criterion. The research was conducted with limited keywords, which left out some articles that haven't included my chosen keywords. While each country has its own laws and legislation, culture, economic and political situations, I compared the drivers and barriers of CSR without considering any of the mentioned characteristics. The mentioned limitations create potential for future research to consider other strategies and methods within the CSR literature, as well as other primary sources of information, such as analyzing how organizations implement CSR in each country.

\section{Conclusions and future research recommendations}

Based on a systematicliterature review of 28 journal articles, this study investigated and compared the drivers and barriers influencing CSR implementation in the MENA region with western countries. My analysis shows some of the CSR drivers such as leadership styles, profitability, reputation, moral commitment, and environmental conservation are similar in both regions. There are also some differences between CSR drivers, for example, religious beliefs, low concentration of ownership, and company characteristics are some of the drivers of CSR in the MENA region. Maintaining social license to operate, avoiding the risks of community opposition, pressure from the government, and consumer demand tend to be more important in western countries.

I also found there are common barriers in both regions, such as lack of financial re sources, cost, lack of CSR knowledge and awareness, and ownership concentration. This review also discovered that lack of law enforcement, lack of stakeholder communication, lack of management commitment, lack of interests, corruption, and financial debts are some of the addressed barriers of CSR in the MENA region, while cost/benefit ratio, lack 
of customer interest, and lack of scientific frameworks are the special barriers in western countries.

This information is significant because it indicated there is a gap in CSR literature, and the MENA region in specific has not been studied in depth by researchers; there is room for future research. While electricity and transportation sectors as well as oil and gas companies are the main contributors to global emissions, there is a vital need to understand what drives these companies towards socially responsible business practices. Future studies could also conduct comparative studies between different industries to identify the differences and similarities of CSR drivers and barriers in various industries.

The findings also reveal that there are many countries in the MENA region that have not been analyzed. Future research could also consider focusing on the neglected areas. Another key area that seems to be missing in the literature is the understanding of the role the COVID-19 pandemic had on CSR implementation in the emerging and developed countries. Due to the fast-growing wave of globalization, it is critical for multi-national companies to discover all of the CSR drivers and barriers in different regions to become more successful internationally. It is also noted that CSR barriers and drivers are varied based on geographicallocations.

\section{Funding:}

Data Availability Statement:

\section{Acknowledgments:}

Conflicts of Interest: Declare conflicts of interest or state "The authors declare no conflict of interest."

\section{References}

1. Branco, M. C., \& Rodrigues, L. L.. Corporate social responsibility and resource-based perspectives. Journal of Business Ethics, 2006, 69(2), pp.111-132.

2. Carroll, A. B. Corporate social responsibility: Evolution of a definitional construct. Business \& society,1999, 38(3), $268-295$.

3. Kolk, A., The social responsibility of international business: From ethics and the environment to CSR and sustainable development. Journal of World Business, 2016, 51(1), pp.23-34.

4. Mzembe, A. N., Lindgreen, A., Maon, F., \& Vanhamme, J. Investigating the drivers of corporate social responsibility in the global tea supply chain: A case study of Eastern Produce Limited in Malawi. Corporate Social Responsibility and Environmental Management, 2016, 23(3), 165-178.

5. Bowen, H. R.. Social Responsibilities of the Businessman. 1953, New York: Harper \& Row.

6. Carroll, A. B. A history of corporate social responsibility: Concepts and practices. The Oxford handbook of corporate social responsibility,2008, 19-46.

7. Davis, K. Can business afford to ignore social responsibilities?. California management review, 1960, 2(3), 70-76.

8. European Commission. Corporate Social Responsibility \& Responsible Business Conduct, 2011, Brussels. Belgium: retrieved from: https://ec.europa.eu/growth/industry/sustainability/corporate-social-responsibility-responsible-business-conduct_en

9. Dahlsrud, A. How Corporate Social Responsibility is Defined: an Analysis of 37 Definitions, Corporate Social Responsibility and Environmental Management, 2008, 15(1). 1-13.

10. Habisch, A., Jonker, J., Wegner, M., \& Schmidpeter, R.. Corporate social responsibility across Europe. Berlin. 2005, Germany: Springer Science \& Business Media.

11. Van Marrewijk, M. Concepts and definitions of CSR and corporate sustainability: Between agency and communion. Journal of business ethics, 2003, 44(2), 95-105.

12. Foran, T. Corporate social responsibility at nine multinational electronics firms in Thailand: a preliminary analysis. 2001, Nautilus Institute, Berkeley, CA.

13. Frederick, W. C., Davis, K., \& Post, J. E. Business and society: Corporate strategy, public policy, ethics. 1998, McGraw-Hill Companies.

14. Reder, A. In Pursuit of Profit, 1994, Putnam, New York.

15. McWilliams, A., \& Siegel, D. Corporate social responsibility: A theory of the firm perspective. Academy of management review, 2004, 26(1), 117-127.

16. Farooq, O., Payaud, M., Merunka, D., \& Valette-Florence, P. The impact of corporate social responsibility on organizational commitment: Exploring multiple mediation mechanisms. Journal of Business Ethics, 2014, 125(4), 563-580.

17. Alizadeh, A., Dirani, K. M., \& Qiu, S. Ethics, code of conduct and ethical climate: implications for human resource development . European Journal of Training and Development. 2020, Doi: 10.1108/EJTD-04-2020-0077. 
18. Rasche, A., Morsing, M., \& Moon, J. (Eds.). Corporate social responsibility: Strategy, communication, governance. 2017, Cambridge, UK: Cambridge University Press.

19. Wollard, Karen Kelly, and Brad Shuck. "Antecedents to employee engagement: A structured review of the literature." Advances in developing human resources 13.4, 2011, 429-446.

20. Nonis, S. A., \& Relyea, C. National culture, education, and antecedent values of corporate social responsibility. Journal of Business Diversity, 2016, 16(1), 60-67.

21. Waldman, David A., et al. "Cultural and leadership predictors of corporate social responsibility values of top management: A GLOBE study of 15 countries." Journal of International Business Studies 37.6, 2006, 823-837.

22. Berenson, M.L., Levine, D.M., \& Krehbiel, T.C, Basic Business Statistics: Concepts and Applications, 10th ed., 2005, PrenticeHall, Englewood Cliffs, NJ.

23. Aguinis, H., \& Glavas, A. What we know and don't know about corporate social responsibility: A review and research agenda. Journal of management, 2012, 38(4), 932-968.

24. Govindan, Kannan, Ali Diabat, and K. Madan Shankar. "Analyzing the drivers of green manufacturing with fuzzy approach." Journal of Cleaner Production, 2015, 96, 182-193.

25. Maignan, Isabelle, and David A. Ralston. "Corporate social responsibility in Europe and the US: Insights from businesses' selfpresentations." Journal of International Business Studies 33.3 (2002): 497-514.

26. Haigh, Matthew, and Marc T. Jones. "The drivers of corporate social responsibility: A critical review." (2006).

27. Lynch-Wood, Gary, David Williamson, and Wyn Jenkins. "The over-reliance on self-regulation in CSR policy." Business Ethics: A European Review 18.1 (2009): 52-65.

28. Muller, Alan, and Ans Kolk. "Extrinsic and intrinsic drivers of corporate social performance: Evidence from foreign and domestic firms in Mexico." Journal of Management studies 47.1 (2010): 1-26.

29. Agudelo, M. A. L., Jóhannsdóttir, L., \& Davídsdóttir, B.. A literature review of the history and evolution of corporate social responsibility. International Journal of Corporate Social Responsibility, 2019, 4(1), 1-23.

30. Lozano, R. A holistic perspective on corporate sustainability drivers. Corporate social responsibility and environmental management, 2015, 22(1), 32-44.

31. Laudal, T. Drivers and barriers of CSR and the size and internationalization of firms. Social Responsibility Journal, 2011, 7(2), 234256.

32. Dhanesh, G. S. Why corporate social responsibility? An analysis of drivers of CSR in India. Management Communication Quarterly, 2015, 29(1), 114-129.

33. Mazutis, D., \& Zintel, C. Leadership and corporate responsibility: A review of the empirical evidence. Annals in Social Responsibility, 2015.

34. Lythreatis, S., Mostafa, A. M. S., \& Wang, X. Participative leadership and organizational identification in SMEs in the MENA Region: Testing the roles of CSR perceptions and pride in membership. Journal of Business Ethics, 2019, 156(3), 635-650.

35. Ananzeh, H., Alshurafat, H., \& Hussainey, K. Do firm characteristics and ownership structure affect corporate philanthropic contributions in Jordan?. Journal of Financial Reporting and Accounting, 2021.

36. Mehahad, M. S., \& Bounar, A. Phosphate mining, corporate social responsibility and community development in the Gantour Basin, Morocco. The Extractive Industries and Society, 2020, 7(1), 170-180.

37. Pinto, L., \& Allui, A. Critical drivers and barriers of corporate social responsibility in Saudi Arabia organizations. The Journal of Asian Finance, Economics, and Business, 2020, 7(11), 259-268.

38. Valmohammadi, C. Investigating corporate social responsibility practices in Iranian organizations: an ISO 26000 perspective. Business Strategy Series, 2011, 12(5), 257-263.

39. Ghasemi, S. \& Nejati, M., Corporate social responsibility: opportunities, drivers and barriers. International Journal of Entrepreneurial Knowledge, 2013,3, 33-37.

40. Lythreatis, S., Mostafa, A. M. S., Pereira, V., Wang, X., \& Del Giudice, M. Servant leadership, CSR perceptions, moral meaningfulness and organizational identification-evidence from the Middle East. International Business Review, 2021, 30(5), 101772.

41. Ditlev-Simonsen, C. D., \& Midttun, A. What motivates managers to pursue corporate responsibility? A survey among key stakeholders. Corporate Social Responsibility and Environmental Management, 2011, 18(1), 25-38.

42. Boukattaya, S., \& Omri, A. Impact of Board Gender Diversity on Corporate Social Responsibility and Irresponsibility: Empirica 1 Evidence from France. Sustainability, 2021, 13(9), 4712.

43. Chkanikova, O., \& Mont, O. Corporate supply chain responsibility: drivers and barriers for sustainable food retailing. Corporate Social Responsibility and Environmental Management, 2015, 22(2), 65-82.

44. Sendlhofer, T. Decoupling from Moral Responsibility for CSR: Employees' Visionary Procrastination at a SME. Journal of Business Ethics, 2020, 1-18.

45. Curran, G. Social licence, corporate social responsibility and coal seam gas: framing the new political dynamics of contestat ion. Energy Policy, 2017, 101, 427-435.

46. Barthorpe, S. Implementing corporate social responsibility in the UK construction industry. Property management, 2010, 28(1), $4-17$.

47. Bolton, S. C., Kim, R. C. H., \& O'Gorman, K. D. Corporate social responsibility as a dynamic internal organizational process: A case study. Journal of Business Ethics, 2011, 101(1), 61-74. 
48. Ekatah, I., Samy, M., Bampton, R., \& Halabi, A. The relationship between corporate social responsibility and profitability: the case of Royal Dutch Shell Plc. Corporate Reputation Review, 2011, 14(4), 249-261.

49. Godos-Díez, J. L., Fernández-Gago, R., Cabeza-García, L., \& Martínez-Campillo, A. Determinants of CSR practices: analysis of the influence of ownership and the management profile mediating effect. Spanish Journal of Finance and Accounting/Revista Española de financiación y contabilidad, 2014, 43(1), 47-68.

50. Dam, L., \& Scholtens, B. Ownership concentration and CSR policy of European multinational enterprises. Journal of Business Ethics, 2013, 118(1): 117-126. doi:10.1007/s10551-012-1574-1

51. Fabrizi, M., Mallin, C., \& Michelon, G. The role of CEO's personal incentives in driving corporate social responsibility. Journal of Business Ethics, 2014, 124(2), 311-326.

52. Angus-Leppan, T., Metcalf, L. and Benn, S. Leadership styles and CSR practice: an examination of sensemaking, institutional drivers and CSR leadership, Journal of Business Ethics, 2010, 93(2), 189-213.

53. Jo, H., \& Harjoto, M. A. Corporate governance and firm value: The impact of corporate social responsibility. Journal of business ethics, 2011, 103(3), 351-383.

54. Jin, K. G., \& Drozdenko, R. G. Relationships among perceived organizational core values, corporate social responsibility, ethics, and organizational performance outcomes: An empirical study of information technology professionals. Journal of Business Ethics, 2010, 92(3), 341-359.

55. Jin, K. G., Drozdenko, R., \& DeLoughy, S. The role of corporate value clusters in ethics, social responsibility, and performance: A study of financial professionals and implications for the financial meltdown. Journal of business ethics, 2013, 112(1), 15-24.

56. El-Bassiouny, D. Corporate social responsibility (CSR) and the developing world: Highlights on the Egyptian case with implications for CSR education. In Ethics, CSR and Sustainability (ECSRS) Education in the Middle East and North Africa (MENA) Region (pp. 34-50). 2020, Routledge.

57. Alotaibi, A., Edum-Fotwe, F., \& Price, A. D. Critical barriers to social responsibility implementation within mega-construction projects: The case of the Kingdom of Saudi Arabia. Sustainability, 2019, 11(6), 1-27.

58. Latapí, M., Jóhannsdóttir, L., Davíðsdóttir, B., \& Morsing, M. The Barriers to Corporate Social Responsibility in the Nordic Energy Sector. Sustainability, 2021, 13(9), 4891. 